\title{
The role of pegaptanib sodium in the suppression of epidural fibrosis in a postlaminectomy rat model
}

\author{
Sertbas $\mathrm{I}^{1}$, Yilmaz $\mathrm{A}^{2}$, Yildirim $\mathrm{T}^{2}$, Karatay $\mathrm{M}^{3}$, Celik $\mathrm{H}^{4}$, Bayar $\mathrm{MA}^{4}$ \\ Bartin State Hospital, Neurosurgery, Bartin, Turkey. mdtimur@hotmail.com
}

\begin{abstract}
OBJECTIVE: Spinal epidural fibrosis is a clinical condition that develops after laminectomy and can compress the spine. Many agents have been tried for the treatment, but none has entered clinical use at present. Pegaptanib sodium is an antiangiogenetic drug that prevents the development of new vessels and thus adhesion by inhibiting the effect of VEGF.

MATERIAL AND METHOD: 20 Wistar rats were used in this study. The rats were divided into 2 different groups as the control and pegaptanib sodium group. Three levels of laminectomy were performed. Only laminectomy was performed in the control group. A cotton ball soaked with $3 \mathrm{mg} / \mathrm{kg}$ Pegaptanib sodium diluted 1: 10 with $0.9 \% \mathrm{NaCl}$ was topically applied to the dura in the surgical field for 5 minutes in the pegaptanib sodium group. The rats were sacrificed 3 weeks later and histopathologically examined. The epidural fibrosis was graded.

RESULTS: The epidural fibrosis grade in the pegaptanib sodium was significantly lower than in the control group $c^{2}=11,65 ;(p=0.004)$

CONCLUSION: Pegaptanib sodium blocked the VEGF through its anti-VEGF effect and decreased spinal epidural fibrosis in rats that had undergone laminectomy (Tab. 2, Fig. 3, Ref. 53). Text in PDF www.elis.sk. KEY WORDS: pegaptanib sodium, laminectomy, epidural fibrosis.
\end{abstract}

\section{Introduction}

Epidural fibrosis is the formation of fibrosis tissue in place of other tissues, such as epidural fat tissue, ligament and bone, removed after laminectomy, hemi-laminectomy and other surgical procedures performed for the treatment of disorders compressing the spinal cord or nerve fibres, and is an important cause of back pain $(1,2,3)$. The compression of and adhesion to the surrounding nerve tissue and dura mater can lead to clinical signs and symptoms $(2,3)$. Epidural fibrosis after surgery is a natural result of surgical trauma. The incidence of the epidural fibrosis is between $20 \%$ and $47 \%$ in various series (4). Although epidural fibrosis develops frequently after decompressive surgery, the rate of developing into a clinical disorder is only $1-2 \%$ in these patients $(5,6,7)$.

Many agents, such as silastic membrane, carboxymethylcellulose, polylactic acid membrane, glucocorticoids, fibrin glue, spongostan, urokinase, sodium hyalunorate, and adcon-L (antiadhesion barrier gel), have been used in order to prevent spinal epidural fibrosis $(5,6,7,8,9,10,11,12,13,14,15)$. Vascular Endothelial Growth Factor (VEGF) is a powerful angiogenic cy-

${ }^{1}$ Bartin State Hospital, Neurosurgery, Bartin, Turkey, ${ }^{2}$ Ordu University School Of Medicine, Neurosurgery, Ordu, Turkey, ${ }^{3}$ Gaziosmanpasa Hospital, Neurosurgery, Istanbul, Turkey, and ${ }^{4}$ Ankara Training And Research Hospital, Neurosurgery, Ankara, Turkey

Address for correspondence: T. Yildirim, Ordu University Faculty Of Medicine, Neurosurgery Deparment, 52200, Ordu, Turkey.

Phone/Fax: +904522252342 tokine. It also participates directly and actively in VEGF tissue regeneration, fibroblast function, wound healing, and inflammatory reactions (16). VEGF plays a role in the formation of new vessels that cause fibrosis after surgery (17). Pegaptanib sodium has proven efficacy in the treatment of neovascular age-related macular degeneration and prevents angiogenesis by attaching to the VEGF 165 isoform $(18,19)$. In this study, we investigated the effect of pegaptanib sodium on epidural fibrosis.

\section{Material and methods}

Animals

Totally, 20 male Wistar type, 8-12-month-old rats weighing 200-250 gr were used in this experimental study. The study was conducted at the Experimental Animals Laboratory of Ankara Training and Research Hospital upon receiving the approval of the local ethics committee. Histopathological analyses were performed at the Pathology Department of Ankara Training and Research Hospital.

\section{Surgical procedure and sample preparation}

Ketamine hydrochloride ( $25 \mathrm{mg} / \mathrm{kg}$; Ketalar, Pfizer, Istanbul) and Xylazine (5 mg/kg; Rompun, Bayer, Istanbul) were administered intravascularly for anaesthesia before the procedure. The rats were put in supine position and their backs were shaved. The surgical area was sterilized with povidone iodine (Batticon, Adeka medicine, Istanbul). The surgical field was then covered with sterile drapes. A midline skin incision was performed over the 
Tab. 1. Histopathological classification of the epidural fibrosis was in accordance with the He criteria.

\begin{tabular}{ll}
\hline Grade 0 & No fibrosis affecting the dura mater \\
\hline Grade I & Fine fibrous bands between fibrous tissue and dura mater \\
\hline Grade II & $\begin{array}{l}\text { Permanent adhesion present in an area less than two thirds of } \\
\text { the laminectomy defect }\end{array}$ \\
\hline Grade III & $\begin{array}{l}\text { Adhesion of fibrosis tissue present in an area more than two } \\
\text { thirds of the laminectomy defect and/or fibrous tissue reaches } \\
\text { the nerve roots }\end{array}$ \\
\hline
\end{tabular}

Tab. 2. Comparison of the histopathology results of the control and treatment groups for epidural fibrosis.

\begin{tabular}{lcccc}
\hline Groups & \multicolumn{4}{c}{ Stage n (\%) } \\
\cline { 2 - 5 } & stage 0 & stage 1 & stage 2 & stage 3 \\
\hline Control & $0(0.0)$ & $0(0.0)$ & $3(30.0)$ & $7(70.0)$ \\
Pegaptanib Sodium & $1(10.0)$ & $6(60.0)$ & $2(20.0)$ & $1(10.0)$ \\
\hline$\chi^{2}=11.65, \mathrm{p}=0.004$ & & & &
\end{tabular}

L1-S1 spinous processes. The paraspinal muscles were dissected by bilateral microdissection. Total laminectomy was performed on the L3, L4 and L5. Epidural fat tissue and ligamentum flavum were cleaned. The dura mater was exposed. A bipolar coagulator was used for hemostasis. No dura or nerve damage occurred. Only laminectomy was performed in the control group. A cotton ball soaked in $3 \mathrm{mg} / \mathrm{kg}$ pegaptanib sodium diluted 1:10 with 0.9 $\% \mathrm{NaCl}$ was topically applied to the dura in the surgical field for 5 minutes in the pegaptanib sodium group. Following hemostasis, the anatomic layers were closed properly one by one. Both the control and the experiment group rats were taken to their cages and provided with routine care. The subjects were kept alive for 3 weeks and then sacrificed by intraperitoneal administration of high-dose (75-100 mg/kg) Thiopental Sodium (Pentothal Sodium, Abbott, Italy). No infection developed in any of the rats. The vertebral column (L3-L4-L5) was removed an bloc.

The block of the vertebral column was fixed in $10 \%$ buffered formaldehyde for 4 days and decalcified with $30 \%$ formic acid for 2 days for histopathology analysis. The amount of the epidural fibrosis at the laminectomy area and its relationship with the dura mater were defined using histopathology classifications and the results were analysed. Three $2 \mathrm{~mm}$-thick transverse spinal cord samples were obtained from the laminectomy region (from the middle, proximal, and distal sections). Following paraffin fixation, 3 micron-thick profiles were taken from the paraffin blocks with a microtome. Hematoxylin and eosin staining was performed for routine histopathological analyses. These preparations were evaluated with a light microscope. Fibrous tissue was defined with the “Zeiss Imager M2" microscope and photographed.

\section{Experimental groups}

Group 1: Control $(\mathrm{n}=10)$; only laminectomy was performed, no treatment was given.

Group 2: Pegaptanib sodium ( $\mathrm{n}=10)$; A cotton ball soaked in $3 \mathrm{mg} / \mathrm{kg}$ pegaptanib sodium (20 he 21 ) diluted with $0.9 \%$ sodium chloride was topically applied to the dura for 5 minutes.

\section{Evaluation of epidural fibrosis}

The epidural fibrosis was graded according to the classification of He et al $(16,20)$ (Tab. 1).

\section{Statistical analysis}

Chi-square analysis (Fisher's Exact test) was used to present the scores of epidural fibrosis depending on the groups (Control and Pegaptanib Sodium). The findings were expressed as the sample size (\%). All the computational work was performed by means of SPSS 21.0 V. $p<0.05$ were accepted as statistically significant.

\section{Results}

The treatment and the control groups were compared using the He criteria for microscopic evaluation. No dura or nerve injury was observed in any of the treatment and the control group subjects during the surgical procedure. There were also no complications due to pegaptanib sodium in any of the subjects in the treatment group. Epidural fibrosis was intense in the control group, but less prominent in the treatment group. Stage 2 epidural fibrosis was present in $30 \%$ and stage 3 in $70 \%$ of the control group. Stage 0 was found in $10 \%$, stage 1 in $60 \%$, stage 2 in $20 \%$ and stage 3 in $10 \%$ in the pegaptanib sodium group (Tab. 2). Epidural fibrosis extended to the dura from beneath the paraspinal muscles and was adherent. Spaces were found between the dura mater around the medulla spinalis and surrounding muscle layer and nerve roots of the treatment group subjects. Occasional dura mater and bundles extending to the peripheral tissue with a small amount of fibroblast proliferation were observed in these spaces. Comparison of the histopathology results of the control and treatment groups for epidural fibrosis indicated less fibrosis in the treatment group, which was statistically significant $\chi^{2}=11.65 ;(p=0.004)$ (Tab. 2, Figs 1, 2, 3).

\section{Discussion}

The reasons of recurrent pain after laminotomy or laminectomy performed during surgery for lumbar disc problems or for other disorders are yet to be explained adequately. The most important etiological factor is thought to be the scar tissue at the epidural region emerging as a natural result of the healing process $(21,22$, $23,24)$. The scar tissue is reported to create adhesions between the tissues, compress peripheral anatomic structures when prominent, restrict nerve root movement and increase their sensitivity, and cause neural atrophy and axonal degeneration due to scar tissue formation $(21,25,26,27)$. Chemotactic factors emerging with the disruption of erythrocytes and platelets following epidural bleeding and fibroblastic cell migration from the paraspinal muscles are the source of post-laminectomy epidural fibrosis. Adhesions occur due to the fibrous connective tissue hyperplasia. Fibroblasts are important repair cells and try to repair the local vertebral lamina defect following activation by inflammatory cytokines and growth factor (transforming growth factor $\beta$ and basic fibroblast growth factor). Fibroblasts transform into fibrocytes with the production of collagen fibre. The fibrous connective tissue turns into scar 


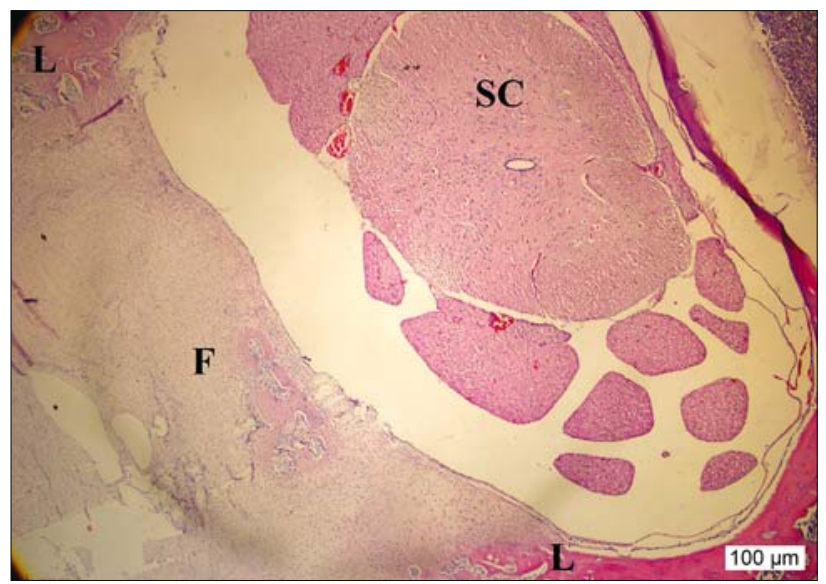

Fig. 1. Stage 3 epidural fibrosis at the control group. SC-Spinal Cord, L- Lamina, F- Fibrosis, Scale bar $=100 \mu \mathrm{m}$.

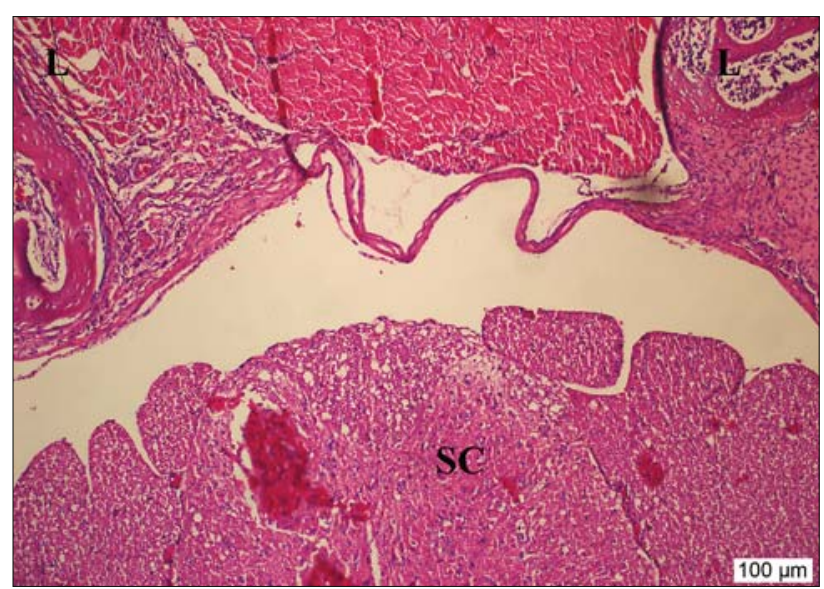

Fig. 2. Stage 0 epidural fibrosis in pegaptanib sodium group. SC- Spinal Cord, $L-$ Lamina, Scale bar $=200 \mu \mathrm{m}$.

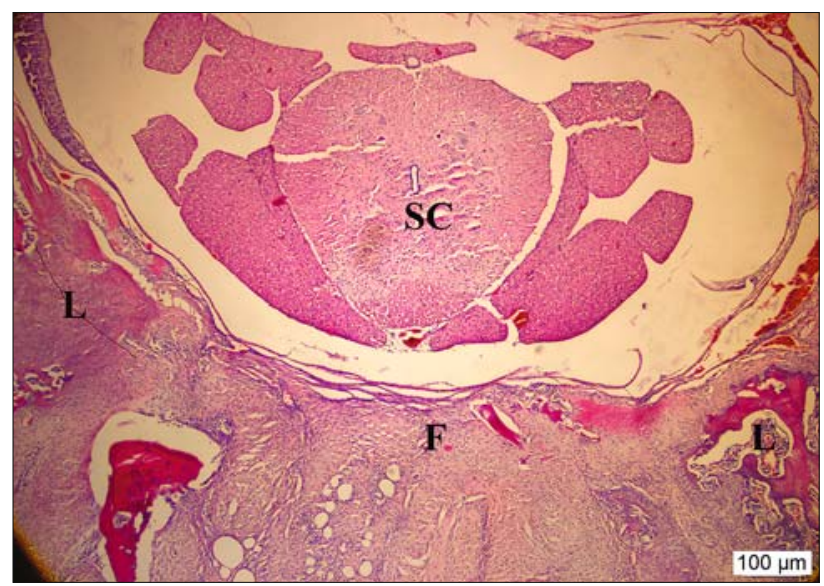

Fig. 3. Stage 1 epidural fibrosis in pegaptanib sodium group. SC- Spinal cord, L- Lamina, F- Fibrosis, Scale bar $=100 \mu \mathrm{m}$.

tissue at the same time. Epidural fibrous tissue can adhere to the dura or the nerve roots at the spinal canal, and gradually turn into a laminectomy membrane. This secondary membrane has been reported to cause spinal stenosis, dural compression and restriction of nerve root mobility $(4,28,29,30,31)$. Repeated surgery to remove the secondary compression caused by epidural fibrosis can increase the fibrosis itself so it is best to try to avoid it in the first operation $(32,33)$.

A large number of experimental and clinical studies have been conducted to prevent epidural fibrosis. The most commonly used substances are Silastic-Dacron gelatin sponge, animal collagen membranes, Adcon-L, autologous fat graft, omental graft, local cortisone, polyvinyl alcohol, vicryl mesh, viscous solution of sodium hyaluronate, urokinase, triamcinolone, ketoprofen, polylactic acid membrane, polytetrafluoroethylene membrane, and recombinant tissue plasminogen activator as fibrinolytic agent gel. Although successful results are reported in most of these studies, routine clinical use cannot be started as there is still no report of sufficient efficacy consistent with clinical improvement in humans $(5,7,34,35)$. The most commonly used substance to prevent epidural fibrosis is autogenous fat tissue. Epidural fat tissue is histopathologically different from subcutaneous fat tissue. Wolfram et al reported that epidural fat tissue consisted of adipocytes and a small amount of connective tissue in a histopathology study (36). Subcutaneous fat tissue contains more connective tissue. This fat tissue is known to decrease dural adhesions, but has a partial inhibitory effect on epidural fibrosis. Bryant et al (37) concluded that autogenous free fat grafts were well tolerated and also prevented epidural fibrosis tissue from progression to the spinal canal with revascularization in the short- and long-term follow-up of 44 patients.

Braverman et al reported that the success rate was only 30-35 $\%$ in cases they operated for epidural fibrosis (38). Epidural fibrosis is known to develop in various degrees in almost all cases after lumbar discectomy. Some investigators have reported that surgical intervention in the epidural space is responsible for the inflammatory reaction that results in the accumulation of collagen deposits caused by fibroblasts coming to the region and that the fibrous tissue may also be the result of surgical complications such as haemorrhage and infection $(39,40)$.

Benoist et al reported no pathological finding other than marked epidural fibrosis in any of the patients during the second surgery in 38 patients, who did not experience pain relief following lumbar disc hernia surgery, and reported adhesive arachnoiditis in 3 cases (39). A study investigating the aetiology of focal spinal arachnoiditis reported that the nucleus pulposus caused fibrosis in the arachnoid membrane and epidural space, and the reason was inflammation due to the nucleus pulposus leaking into the epidural space. The rate and the persistence of arachnoiditis and neural degeneration have been reported to increase in the presence of foreign bodies, and the occurrence of axonal degeneration of the cauda equina to be more common in the dorsal aspect that faces the scar tissue. Some investigators have reported that cotton fibres remaining after surgery play a role in the aetiology of epidural fibrosis and arachnoiditis (40, 41, 42, 43 ). The success rate of surgery for epidural fibrotic changes is $30-37 \%$, while $10-20 \%$ of the cases have been reported to deteriorate (44). North et al (45) reported good results in patients 
with mostly radicular pain, but no epidural fibrosis requiring surgical intervention. Epidural fibrosis indicated poor prognosis as demonstrated by such patients undergoing 2-4 surgeries in average with a success rate of $34 \%$. Fager et al (31) reported improvement in $1 \%$ of the re-operated cases and no change in 34 $\%$, while $25 \%$ got worse afterwards. Jayson et al (46) reported good results in patients operated for recurrent disc hernia and lumbar stenosis, but poor results in epidural fibrosis. VEGF is an important factor in the development of angiogenesis $(47,48)$. It is a multifunctional growth factor with specific effects on endothelial cells in particular (49). The VEGF family has been shown to consist of six members: VEGF-A (Human-VEGF), VEGFB, VEGF-C, VEGF-D, VEGF-E and Placental growth factor, PIGF (22). VEGF-A has six known isoforms; namely, VEGF121, VEGF145, VEGF165, VEGF183, VEGF189 and VEGF206; the numbers indicating the number of amino acids (50). VEGF is important and necessary for vasculogenesis and angiogenesis, both during development and in adults (51). This growth factor plays a critical role in the development of vessels in particular, but is also necessary for many endothelial cell functions. These physiological and pathophysiological events include embryogenesis, wound healing, tumour growth, myocardial ischemia, ocular neovascular diseases, and inflammatory disorders. Pegaptanib sodium has been proven to be clinically effective by preventing angiogenesis with its anti-VEGF characteristics in neovascular age-related macular degeneration in literature $(15,19,45,52)$. The effect of bevacizumab, which has a mechanism of action similar to pegaptanib sodium, in preventing spinal epidural fibrosis has been demonstrated with the experimental study conducted by Karatay et al (53). We found that the epidural fibrosis in the control group subjects filled the epidural space by completely covering the dura, progressed beneath the pedicle and extended to the spinal roots. However, the fibrosis tissue on the dura was thinner in rats, which received pegaptanib sodium. Epidural fibrosis was intense in the control group but was less prominent in the pegaptanib sodium group, and the difference was statistically significant $(\mathrm{p}=0,001)$. Our study was the first study investigating the effect of pegaptanib sodium on spinal epidural fibrosis. We found that topically applied pegaptanib sodium significantly decreased spinal epidural fibrosis with an anti-VEGF effect in rats that had undergone laminectomy.

\section{References}

1. Horlein BF, Redding RW, Hoff EJ, McGuire JA. Evaluation of naloxane, crocetin, thyrotropin releasing hormone, methylprednizolone, partial myelotomy and hemilaminectomy in the treatment of acute spinal cord trauma. JAAHA 1985; 21: 68-77.

2. LaRocca H, Macnab I. The laminectomy membrane. Studies in its evolution, characteristics, effects and prophylaxis in dogs. J Bone Joint Surg Br 1974; 56: 545-550.

3. Trotter EJ, Brasmer TH, DeLahunta A. Modified deep dorsal laminectomy in the dog. Cornell Vet 1975; 65: 402-427.

4. Manchikanti L. Epidemiology of low back pain. Pain Physician 2000; 3: $167-192$.
5. Alkalay RN, Kim DH, Urry DW, Xu J, Parker TM, Glazer PA. Prevention of postlaminectomy epidural fibrosis using bioelastic materials. Spine 2003; 28: 1659-1665.

6. Setti S, Rengachary and Raju S.V Balabhadra. Black disc disease: a commentary, Neurosurg Focus 2002; 13: 14.

7. Geisler FH. Prevention of epidural fibrosis: current methodologies. Neurol Res 1999; 21: 9-22.

8. Annertz M, Jönsson B, Strömqvist B, Holtås S. No relationship between epidural fibrosis and sciatica in the lumbar postdiscectomy syndrome. A study with contrast-enhanced magnetic resonance imaging in symptomatic and asymptomatic patients. Spine 1995; 20: 449-453.

9. Frederickson RCA, Adcon L. A review of its development, mechanism of action, and preclinical data. Eur Spine J 1996; 5: 7-9.

10. Kitano T, Zerwekh IE, Edwards ML, Usui Y, Allen MD. Viscous carboxymethyl cellulose in the prevention of epidural scar formation. Spine 1991; 16: 820-823.

11. Kiviluoto O. Use of free fat transplants to prevent epidural scar formation. An experimental Study. Acta Orthop Sc Supply 1976; 164: 3-75.

12. Robertson JT, Petrie JL, Frederickson RCA, De Tribolet N, Hardy R. ADCON-L Symposium. Round table discussion. Eur Spine J 1996; 5: 26-28.

13. Trotter EJ, Brasmer J, Robson D, Babish J. Influence of nonbiologic implants on laminectomy membrane formation in dogs. Am J Vet Res 1988; 49: 634-643.

14. Van Akkerveeken PF, Van de Kraan W, Muller JW. The Fate of the free fat graft. A prospective clinical study using CT scanning. Spine 1986; 11: 501-504.

15. Gragoudas ES, Adamis AP, Cunningham ET Jr, Feinsod M, Guyer DR. VEGF Inhibition Study In Ocular Neovascularization Clinical Trial Group: Pegaptanib for neovascular age-related macular degeneration. N Engl J Med. 2004; 351: 2805-2816.

16. Howdieshell TR, Callaway D, Webb WL, Gaines MD, Procter CD Jr, Sathyanarayana, Pollock JS, Brock TL, McNeil PL. Antibody neutralization of vascular endothelial growth factor inhibits wound granulation tissue formation. J Surg Res 2001; 96: 173-182.

17. Diamond MP, El-Hammady E, Munkarah A, Bieber EJ, Saed G. Modulation of the expression of vascular endothelial growth factor in human broblasts. Fertil Steril 2005; 83: 405-409.

18. Bell C, Lynam E, Landfair DJ, Janjic N, Wiles ME. Oligonucleotide NX1838 inhibits VEGF165-mediated cellular responses in vitro. In Vitro Cell Dev Biol Anim 1999; 35: 533-542.

19. Shukla D, Namperumalsamy P, Goldbaum M, Cunningham ET Jr. Pegaptanib sodium for ocular vascular disease. Indian J Ophthalmol 2007; 55: 427-430.

20. He Y, Revel M, Loty B. A quantitative model of postlaminectomy scar formation. Effects of a nonsteroidal antiinflammatory drug. Spine 1995; 20: 557-563.

21. Martin-Ferrer S. Failure of autologous fat grafts to prevent postoperative epidural fibrosis in surgery of the lumbar spine. Neurosurgery 1989; 24: 718-721.

22. Pennigton B, McCarron RF, Laros GS. Identification of Ig G in the canine intervertebral disc. Spine 1988; 13: 909-912.

23. Carroll SE, Wiesel SW. Neurologic complications and lumbar laminectomy. Clin Orthop Rel Res 1992; 284: 14-23. 
$118-122$

24. Boden SD, Davis DO, Dina TS, Parker CP, O'Malley S, Sunner JL, Wiesel SW. Contrast enhanced MR imaging performed after successful lumbar disc surgery: prospective study. Radiology 1992; 182: 59-64.

25. Boot DA, Hughes SPF. The prevention of adhesions after laminectomy. Adverse results of Zenodermim plantations into laminectomy sites in rabbits. Clin Orthop Rel Res 1987; 215: 296-302.

26. Brodsky AE. Post- laminectomy and post-fusion stenosis of the lumbar spine. Clin Orthop Rel Res 1976; 115: 130-138.

27. Gerszten PC, Moossy JJ, Flickinger JC, Gerszten K, Kalend A, Martínez AJ. Inhibition of peridural fibrosis after laminectomy using low-dose external beam radiation in a dog model. Neurosurgery 2000; 46: 1478-1485.

28. Rodgers KE, Robertson JT, Espinoza T, Oppelt W, Cortese S, diZerega GS, Berg RA. Reduction of epidural fibrosis in lumbar surgery with Oxiplex adhesion barriers of carboxymethylcellulose and polyethylene oxide. Spine J. 2003; 3: 277-283; discussion 284.

29. Huang SC, Lai HC, Tsai IC. Treatment of pseudomonas keratoscleritis after pterygium excision. Cornea 1999; 18: 608-611.

30. Epstein NE, Schwall G. Thoracic spinal stenosis. Diagnostic and treatment challenges. J Spinal Disord 1994; 7: 259-269.

31. Fager CA, Freidberk SR. Analysis of failures and poor results of lumbar spine surgery. Spine 1980; 5: 87-94.

32. Jayson MIV. Vascular damage fibrosis and chronic inflammation in low back pain and sciatica. In: Jayson MIV (Ed). The lumbar spine and back pain. Edinburgh: Churchill-Livingstone, 1992; 101-109.

33. Mejía LF, Acosta C, Santamaría JP. Use of nonpreserved human amniotic membrane for the reconstruction of the ocular surface. Cornea 2000; 19: 288-291.

34. Temel SG, Ozturk C, Temiz A, Ersozlu S, Aydinli U. A new material for prevention of epidural fibrosis after laminectomy. J Spinal Disord Tech 2006; 19: 270-275.

35. Gorgulu A, Simsek O, Cobanoglu S, Imer M, Parsak T. The effect of epidural free fat graft on the outcome of lumbar disc surgery. Neurosurg Rev 2004; 27: 181-184.

36. Wolfram-Gabel R, Beaujeux R, Fabre M, Kehrli P, Dietemann JL, Bourjat P. Histologic characteristics of posterior lumbar epidural fatty tissue. J Neuroradiol 1998; 23: 19-25.

37. Bryant MS, Bremer AM, Nyugen TQ. Autogeneic fat transplants in the epidural space in Routine lumbar spine: MR imaging assessment. AJNR 1988; 9: 169-178.

38. Braverman DL, Slipman CW, Lendrow DA. Using gabapentin to treat failed back surgery Syndrome caused by epidural fibrosis: a report of two cases. Arch Phys Med Rehab 2001; 82: 691-693.
39. Benoist M, Ficat C, Baraf P, Cauchoix J. Postoperative lumbar epiduro-aracnoiditis. Diagnostic and therapeutic aspects. Spine 1980; 5: $432-436$.

40. Hoyland JA, Freemont AJ, Denton J, Thomas AMC, McMillian JJ, Jasyon MIV. Reteined surgical swab debris in post-laminectomy aracnoiditis and peridural fibrosis. J Bone Joint Surg (Br) 1988; 70: 659-662.

41. Haughton VM, Nyugen CM, Ho K-C. The etiology of focal spinal aracnoiditis: An Experimental Study. Spine 1993; 18: 1193-1198.

42. Jayson MIV. The Role of vascular damage and fibrosis in the pathogenesis of nerve root damage. Clin Orthopd Rel Res 1992; 279: 40-48.

43. Yamagami T, Matsui H, Tsuji H, Ichimura K, Sano A. Effects of laminectomy and retained extradural foreign body on cauda equina adhesion. Spine 1993; 18: 1774-1781.

44. Samy AM, Hardy RW. Epidural fibrosis and the failed back surgery syndrome: history and physical findings. Neurol Res 1999; 21: 55-58.

45. North RB, Campbell JN, James CS, Conover-Walker MK, Wang H, Piantadosi S, Rybock JD, Long DM. Failed Back surgery Syndrome: 5-Year Follow up in 102 Patients undergoing Repeated Operation. Neurosurgery $1991 ; 28$ : 685-691.

46. Jayson MIV. Vascular damage, fibrosis, and chronic inflammation in mechanical back pain problems. Sem Arthrit Rheum 1989; 18: 73-76.

47. Presta LG, Chen H, O'Connor SJ, Chisholm V, Meng YG, Krummen L, Winkler M, Ferrara N. Humanization of an anti-VEGF mono clonal antibody for the therapy of solid tumors and other disorders. Cancer Res 1997; 57: 4593-4599.

48. Tran J, Master Z, Yu JL, Rak J, Dumont DJ, Kerbel RS. A role for surviving in chemoresistance of endothelial cells mediated by VEGF. Proc Natl Acad Sci USA 2002; 99: 4349-4354.

49. Yancopoulos GD, Davis S, Gale NW, Rudge JS, Wiegand SJ, Holash J. Vascular-specific growth factors and blood vessel formation. Nature 2000; 407: 242-248.

50. Zachary I. Vascular endothelial growth factor. Int J Biochem Cell Biol 1998; 30: 1169-1174.

51. Shalaby R, Rossant J, Yamaguchi TP, Gertsenstein M, Wu X, Breitman MLet al. Failure of blood-island formation and vasculogenesis in Flk-1 deficient mice. Nature 1995; 376: 62.

52. Atmani K, Coscas F, Coscas G, Soubrane G. Pegaptanib sodium for occult choroidal neovascularization in neovascular age-related macular degeneration: a prospective case series. Eye (Lond) 2009; 23: 1150-1154.

53. Karatay M, Erdem Y, Koktekir E, Erkoc YS, Caydere M, Bayar MA. The effect of Bevacizumab on spinal epidural fibrosis in a postlaminectomy rat model. Turk Neurosurg 2012; 22: 753-757.

Received September 26, 2016. Accepted November 7, 2016. 